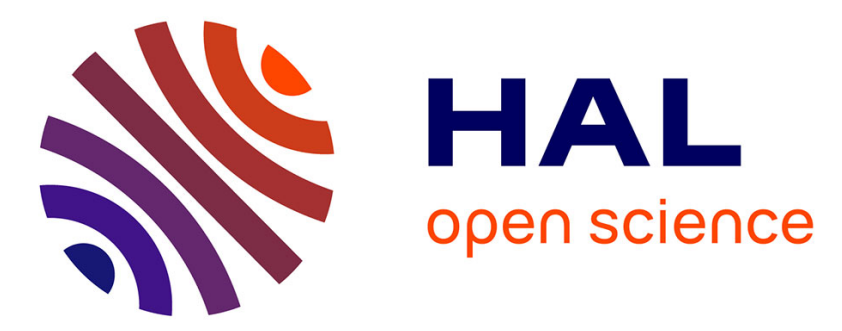

\title{
Peptidoglycan derived from S. epidermidis induces Connexin43 hemichannel activity with consequences on the innate immune response in endothelial cells.
} Jennifer Robertson, Sue Lang, Peter A Lambert, Patricia E Martin

\section{- To cite this version:}

Jennifer Robertson, Sue Lang, Peter A Lambert, Patricia E Martin. Peptidoglycan derived from S. epidermidis induces Connexin43 hemichannel activity with consequences on the innate immune response in endothelial cells.. Biochemical Journal, 2010, 432 (1), pp.133-143. 10.1042/BJ20091753 . hal-00529102

\author{
HAL Id: hal-00529102 \\ https://hal.science/hal-00529102
}

Submitted on 25 Oct 2010

HAL is a multi-disciplinary open access archive for the deposit and dissemination of scientific research documents, whether they are published or not. The documents may come from teaching and research institutions in France or abroad, or from public or private research centers.
L'archive ouverte pluridisciplinaire HAL, est destinée au dépôt et à la diffusion de documents scientifiques de niveau recherche, publiés ou non, émanant des établissements d'enseignement et de recherche français ou étrangers, des laboratoires publics ou privés. 
Peptidoglycan derived from $S$. epidermidis induces Connexin43 hemichannel activity with consequences on the innate immune response in endothelial cells.

Jennifer Robertson, Sue Lang, Peter A. Lambert", Patricia E Martin*.

Department of Biological and Biomedical Sciences, Glasgow Caledonian University, Cowcaddens Road, Glasgow, G4 0BA, UK, "School of Health and Life Sciences, Aston University, Aston Triangle, Birmingham, B4 7E, UK

* Corresponding Author:

Dr Patricia E Martin

Department of Biological and Biomedical Sciences

Glasgow Caledonian University

Glasgow

G4 0BA

$\mathrm{UK}$

Tel: $+44(0) 1413313726$

FAX: +44 (0) 1413313208

Email: patricia.martin@gcu.ac.uk

Running title: Peptidoglycan enhances Connexin43 expression and hemichannel activity

Key words: Connexin 43; hemichannel; peptidoglycan; innate immunity.

Total word count: 5,060

Number of Figures: 8

Number of Tables: 1

\begin{abstract}
Abbreviations:
ATP: Adenosine triphosphate; CBX: Carbenoxolone; Cx: Connexin; DTT: Dithiothreitol; IL-6: Interleukin 6; $\mathrm{LnCl}_{3}$ : LN, LPS: Lipopolysaccharide; LTA: Lipoteichoic acid; NAD: Nicotinamide adenine dinucleotide; Panx: Pannexin; PGN: Peptidoglycan; PKC: Protein kinase C; PMSF: Phenylmethanesulfonyl fluoride; TLR: Toll-Like Receptor; $18 \alpha$-GA: $18 \alpha$-glycerrhetinic acid.
\end{abstract}

Abstract 
Gram-positive bacterial cell wall components including peptidoglycan (PGN) elicit a potent pro-inflammatory response in diverse cell types including endothelial cells by activating TLR2 signalling. The functional integrity of the endothelium is under the influence of a network of gap junction intercellular communication channels composed of connexins (Cxs) that also form hemichannels, signalling conduits implicated in ATP release and purinergic signalling. PGN modulates connexin expression in a variety of cell types yet effects in endothelial cells remain unresolved. Using the endothelial cell line b.End5, a $6 \mathrm{~h}$ challenge with PGN induced IL-6, TLR2 and $\mathrm{Cx} 43$ mRNA expression that was associated with enhanced Cx43 protein expression and GJ coupling. Cx43 hemichannel activity, measured by ATP release from the cells, was induced following $15 \mathrm{~min}$ exposure to PGN. Inhibition of hemichannel activity with carbenoxolone or apyrase prevented induction of IL-6 and TLR2 mRNA expression by PGN but had no effect on Cx43 mRNA expression levels. By contrast knockdown of TLR2 expression had no effect on PGN induced hemichannel activity but reduced the level of TLR2 and Cx43 mRNA expression following $6 \mathrm{~h}$ PGN challenge. PGN also acutely induced hemichannel activity in HeLa cells transfected to express $\mathrm{Cx} 43$ but had no effect in $\mathrm{Cx} 43$ deficient HeLa OHIO cells. All ATP responses were blocked with Cx-specific channel blockers. We conclude that acute $\mathrm{Cx} 43$ hemichannel signalling plays a role in initiation of early innate immune responses in the endothelium. 


\section{Introduction}

The highly responsive endothelial lining of the vasculature system plays a central role in regulating vascular behaviour including vascular tone and responses to inflammatory agents $[1,2]$. Central to endothelial function is the ability of the cells of the endothelial layer to co-ordinate responses and exchange regulatory information between themselves (homocellular communication) or between endothelial cells and their neighbours such as smooth muscle cells (heterocellular communication) [3], or transiently between endothelial cells and cells of the immune system [4]. Such intimate and direct cell to cell communication is provided by a network of gap junction intercellular communication channels that permit the exchange of small regulatory molecules and metabolites between neighbouring cells [5]. The constituent proteins of these channels are a highly conserved family of proteins, the Cxs, of which 21 subtypes have been identified in man with $\mathrm{Cx} 43$ being the dominant $\mathrm{Cx}$ expressed in the vascular system. Cxs share a common topology spanning the membrane four times with two highly conserved extracellular loops and cytoplasmically located amino and carboxy termini and one intracellular loop. Six Cxs oligomerise to form a connexon, or hemichannel, that is trafficked in a closed state to the plasma membrane where they laterally accrete to align and dock with a hemichannel from a neighbouring cell [5]. Hemichannels are not just inert precursors of the gap junction unit but can be induced to open by a diverse range of 'environmental' stimuli resulting in the release of paracrine signalling molecules such as ATP, NAD, glutamate and prostaglandins [6]. ATP is important in purinergic signalling especially in endothelial cells where it has a vital role in vascular tone, synaptic transmission and cell death [7]. ATP also increases leukocyte locomotion and adhesion to endothelial cells via purinergic receptors [7] and augments the immune response by inducing cytokines such as IL-6 [8].

Lipopolysaccharide (LPS), a major cell wall component of Gram-negative bacteria, induces pro-inflammatory cytokines and the expression of adhesion molecules on endothelial cells [9]. This inflammatory mediator modulates connexin expression and gap junction communication in aortic endothelium [10], astrocytes and microglia [11]. Furthermore stimulation of cells with LPS induces a transient release of ATP, associated with hemichannel activity and downstream purinergic signalling events [7, 12]. Among the Gram-positive bacteria, the staphylococci are prevalent pathogens and are responsible for a number of infections. A major aetiological agent of deepseated abscesses is Staphylococcus aureus, for example brain abscess. S. aureus has been reported to differentially influence Cx mediated signalling events in astrocytes and microglia $[13,14]$. Staphylococcus epidermidis is particularly noted for its association with medical device-related infections through its ability to form biofilms on the surface of devices, and is the causative agent of infective endocarditis associated with artificial heart valves, characterised by growth of a cardiac vegetation and localised endothelial inflammation $[15,16]$. Two of the gram-positive bacterial cell wall components, namely peptidoglycan (PGN) and Lipoteicohic acid (LTA) are potent pro-inflammatory mediators in many cell types including endothelial cells and PGN extracted from $S$. aureus influences $C x$ expression in astrocytes and microglia $[13,14]$. However, the consequences of these pro-inflammatory mediators on the endothelial gap junction network and $\mathrm{Cx}$ mediated signalling events remain unresolved.

In the present work we have explored the impact of PGN, extracted from $S$. epidermidis NCIMB 40896 that was previously isolated from a patient with infective 
endocarditis [17], on Cx expression and hemichannel signalling events in the b.End5 model endothelial cell line. Our data show that within $15 \mathrm{~min}$ of challenge PGN induced $\mathrm{Cx} 43$ hemichannel opening and a rapid post translational modification of Cx43 protein. Further exposure (6-12 h) resulted in a transient increase in IL-6, TLR2 and Cx43 mRNA expression. Attenuation of the acute hemichannel activity with a panel of Cx specific hemichannel blockers prevented PGN induced IL-6 and TLR2 mRNA expression but had no effect on the induction of $\mathrm{Cx} 43$ mRNA expression. By contrast inhibition of TLR2 expression impacted on Cx43 mRNA expression but had no effect on acute hemichannel opening. Together the results suggest an acute role for hemichannel signalling events in initiation of early innate immune responses.

\section{Materials and Methods}

Cell culture: A murine endothelial cell line (b.End5) derived from murine brain endothelial cells (ECACC 96091930) [18], HeLa OHIO (wild type) cells and HeLa cells transfected to express Cx43 (HeLa43) were used in these studies. All cells were grown in DMEM (Cambrex), (glucose, $4.5 \mathrm{~g} / \mathrm{L}$ ), supplemented with $10 \%$ foetal calf serum, L-glutamine $(2 \mathrm{mM})$, and penicillin/streptomycin $(50 \mathrm{U} / \mathrm{mL}$ (cDMEM), with HeLa43 cells further supplemented with puromycin $(0.5 \mu \mathrm{g} / \mathrm{ml})[19,20]$. Cells were incubated at $37^{\circ} \mathrm{C}$ and $5 \% \mathrm{CO}_{2}$ and maintained and used at $\sim 80 \%$ confluency.

Transfection studies: HeLa OHIO cells were transfected with green fluorescent protein (GFP) tagged Cx43 (Cx43-GFP) in the expression vector backbone pEGFPN1 (Clontech), prepared as previously described [21]. Twelve-well plates of HeLa OHIO cells $\left(2 \times 10^{5}\right.$ cells $)$ were subsequently transfected with $0.5 \mu \mathrm{g}$ of pEGFP-N1 or Cx43-GFP cDNA using Lipofectamine 2000 according to the manufacturer's instructions (Invitrogen, Glasgow, U.K.) [21] and functional assays performed $48 \mathrm{~h}$ post transfection as required.

TLR2 siRNA transfection: Pre-designed siRNA duplexes for TLR2 were purchased from IDT DNA technology (www.idtdna.com) and transfection conditions were optimised using a TYE $563^{\mathrm{tm}}$-labeled transfection control RNA duplex. A scrambled universal negative control duplex was used in all experiments. Cells were transfected with $0.1 \mathrm{nM}$ siRNA using TriFECTin according to manufacturer's instructions (www.idtdna.com). Twenty four hours post transfection cells were challenged as required and functional assays performed as required.

Extraction of bacterial cell wall components: PGN was isolated from $S$. epidermidis NCIMB 40896, as previously described [17]. Briefly, bacterial cell wall sacculi comprising PGN and covalently linked wall teichoic acid (WTA) were prepared by boiling a whole-cell suspension for $30 \mathrm{~min}$ in a solution of SDS followed by thorough washing [22]. WTA was released from the protein- and lipid-free cell wall sacculi with $0.1 \mathrm{M} \mathrm{NaOH}$ and the PGN was solubilized with lysostaphin (Sigma) [17]. Purified PGN was freeze-dried and dissolved in pyrogen-free water to $10 \mathrm{mg} / \mathrm{ml}$ (Versol water for Irrigation; Laboratoire Aguettant). Levels of contaminating LPS in the PGN preparation was measured by the quantitative chromogenic limulus amoebocyte lysate assay (LAL) (QCL-1000; BioWhittaker) according to the manufacturer's instructions. Responses to PGN were compared to that of LPS isolated from Escherichia coli O111:B4 by phenol extraction (Sigma). 
Challenge of cells: Cells were challenged with PGN at concentrations from $0.1-10$ $\mu \mathrm{g} / \mathrm{ml}$ for times ranging from $5 \mathrm{~min}$ to $24 \mathrm{~h}$ in the presence or absence of a variety of known hemichannel blockers including carbonoxolone (CBX) $(100 \mu \mathrm{M})$ [23],

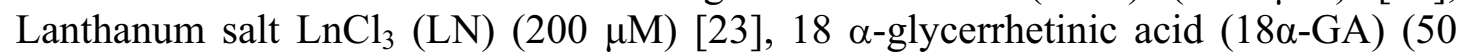
$\mu \mathrm{M})[24]$ and the Cx mimetic peptide Gap26 $(100 \mu \mathrm{M})[24,25]$. In some experiments cells were exposed to the protein kinase $C$ (PKC) inhibitor Chelerythrine $(50 \mathrm{mM})$ for $15 \mathrm{~min}$ prior to PGN challenge. In other experiments cells were pre-exposed to apyrase $(40 \mathrm{U} / \mathrm{ml})$ for $30 \mathrm{~min}$ prior to experiments as previously described [21]. At set time points following challenge, supernatants and cell extracts were harvested for further analysis as required. Cells were assayed for viability using Trypan blue exclusion and Lactate dehydrogenase (LDH) levels in the media were measured using a colorimetric assay according to manufacturer's instructions (Sigma).

ELISA: b.End5 cells $\left(2 \times 10^{5}\right)$ were plated onto 12 -well plates and challenged with PGN, $(0.1-10 \mu \mathrm{g} / \mathrm{ml})$ for up to $24 \mathrm{~h}$. Culture supernatants were harvested and assayed for IL-6 levels by ELISA (Peprotech) according manufacturer's instructions.

Reverse-transcription PCR: Total RNA was isolated using a Mini RNA Isolation Kit (Zymo Research; R1031) as per manufacturer's instructions. Contamination with DNA was avoided by treating total RNA with DNasel (Promega) and cDNA was synthesised using M-ML-V kit (Promega). Standard PCR reactions were subsequently performed to determine gene expression of Cx43, Cx40 and Cx37 using specific primer sequences (Table 1) in an Applied Biosystems 2720 Thermo cycler. GAPDH was used as an internal control. The target sequence was amplified following an initial denaturation step at $95^{\circ} \mathrm{C}$ for $10 \mathrm{~min}$, followed by 30 cycles of $95^{\circ} \mathrm{C}$ for $30 \mathrm{~s}$, $30 \mathrm{~s}$ annealing time at temperatures dependent on the primer set (table 1), an extension step of $72^{\circ} \mathrm{C}$ for $30 \mathrm{~s}$, and a final extension time of $72^{\circ} \mathrm{C}$ for $10 \mathrm{~min}$. All samples were analysed by electrophoresis on $1 \%$ agarose gels. Mouse genomic DNA was used as a positive control and DNase /RNase free water was used as a negative control.

Real-time PCR: To quantify changes in Cx43 and IL-6 expression real time PCR analysis was performed. Primers and probes were designed with sequence data from Gen-Bank and the real-time RT-PCR probe/primer design software Primer Express (version 1.0, PerkinElmer), which optimized the sequences for use in RT-PCR (Table 1). PCR conditions were optimized with respect to concentrations of $\mathrm{MgCl}_{2}$, probe, and both primers to maximize signal. The final PCR mixture contained $10 \mu \mathrm{l}$ of PCR mix (PeqLab), primers (100 nM) and probe (100 nM) and cDNA (400 ng). Real-time PCR was performed in an Opticon 2 unit under the following cycling conditions: $95^{\circ} \mathrm{C}$ for $15 \mathrm{~min}$, followed by 40 cycles of $95^{\circ} \mathrm{C}$ for $15 \mathrm{~s}$ and $60^{\circ} \mathrm{C}$ for $1 \mathrm{~min}$. The mRNA levels were obtained from the value of threshold cycle $(C t)$ for each specific gene and normalized against the $C \mathrm{t}$ of GAPDH ( $\Delta \Delta \mathrm{Ct}$ method).

Western Blot: Cells, grown to confluency on 6 well plates prior to challenge with PGN were harvested in $100 \mu$ l of ice-cold lysis buffer $\left(1 \%\right.$ SDS v/v, $1 \mathrm{mM} \mathrm{Na}_{3} \mathrm{VO}_{4}$ (Sigma), 1mM DTT (Sigma), $100 \mu \mathrm{M}$ PMSF (Sigma), 0.01\% v/v protease inhibitor cocktail (Sigma). Total protein $(25 \mu \mathrm{g})$ was run on a $10 \%$ SDS polyacrylamide gel, and transferred to a nitrocellulose membrane (GE Healthcare Ltd, United Kingdom) in transfer buffer (25 mM Tris, $200 \mathrm{mM}$ glycine and 20\% v/v methanol) as previously described [26]. Membranes were blocked with 5\% w/v skimmed milk in TBS-T (200 
$\mathrm{mM}$ Tris, $1.5 \mathrm{mM} \mathrm{NaCl} 0.1 \% \mathrm{v} / \mathrm{v}$ Tween 20 ), and probed with primary antibodies targeted to $\mathrm{Cx} 43$ (rCx43 kindly provided by Dr E.Rivedal, [27], Cx43 ser368 (New England Biolab; 3511S), TLR2 (Abcam) or $\beta$-tubulin at dilutions of 1:10,000, 1:500, $1: 200$ and 1:2,000 respectively at $4{ }^{\circ} \mathrm{C}$ overnight. Primary antibodies were visualized using anti-mouse or -rabbit horse raddish peroxidase (HRP) (1:2000 dilution) followed by chemiluminescent detection (ECL Plus [RPN2124], GE Healthcare Ltd) and exposure to Hyperfilm followed by quantification using a densitometer with the Quantity one programme as previously described [26].

Microinjections: Cells were grown to confluency in $60 \mathrm{~mm}$ Petri dishes and challenged with PGN for 6 or $24 \mathrm{~h}$. Individual cells were microinjected with Alexa 488 (MW 570) (Invitrogen, UK) using an Eppendorf 5120 femtojet microinjection system linked to a Cairns monochromator with $\sim 50$ cells injected per experimental group [26]. Following injection cells were incubated at room temperature for $5 \mathrm{~min}$ and fixed in $3.7 \% \mathrm{v} / \mathrm{v}$ formaldehyde and the number of cells the dye had transferred to were counted. Data are presented as the average extent of dye spread from individually injected cells \pm SEM. Experiments were repeated in triplicate.

Hemichannel Functionality: Cells $\left(2 \times 10^{5}\right)$ were plated on 12-well plates and the following day challenged in $1 \mathrm{ml}$ of media containing $0.1 \mu \mathrm{g} / \mathrm{ml}$ PGN in the presence or absence of the hemichannel blockers outlined above. As a positive control cells were also challenged with DTT $(10 \mathrm{mM})$ [23]. Medium was harvested $(500 \mu \mathrm{l}$ from $1000 \mu \mathrm{l})$ and snap frozen on dry ice. Cells were washed in ice cold PBS and any excess liquid removed prior to harvesting in $500 \mu \mathrm{l}$ of $5 \% \mathrm{v} / \mathrm{v}$ trichloroacetic acid (TCA). The total amount of protein in each sample was subsequently measured by BioRad DC protein assay kit following the manufacturer's instructions. To measure extracellular ATP, the samples were thawed on ice and levels of ATP in the media determined using the Sigma luciferin-luciferase assay as previously described [24]. To standardise the results data were calculated as the concentration of ATP (nM) per $\mu \mathrm{g}$ of protein and results are presented as the percentage ATP release compared to controls.

To measure levels of NAD present in the media, samples were collected following treatments and analysed using an NAD/NADH assay kit from Abcam (ab65348) following the manufacturer's instructions. The NAD/NADH ratio is calculated as: $[\mathrm{NADt}-\mathrm{NADH}] / \mathrm{NADH}$.

Statistical Analysis: Experiments were performed in triplicate per setting and repeated three times. Statistical analysis was performed using GraphPad Prism. Results are expressed as mean \pm SEM and student t-tests were used to determine statistical significance $\mathrm{P}<0.05$ was considered significant.

\section{Results}

\section{PGN induces a pro-inflammatory response in b.End5:}

LPS contamination of PGN extracts is often associated with commercially sourced PGN [28]. LAL assays determined that our purified PGN extracts from S. epidermidis NCIMB 40896 had less than $0.4 \mathrm{EU} / \mathrm{ml}$ LPS, significantly lower than the commercial supply thereby confirming its purity (not shown). To confirm that PGN triggered a pro-inflammatory response, b.End5 cells were initially challenged with $0.1,1$ or 10 
$\mu \mathrm{g} / \mathrm{ml}$ of PGN and the level of IL-6 produced determined by ELISA. A sequential increase in IL-6 production occurred with $0.1 \mu \mathrm{g} / \mathrm{ml}$ inducing a significant protein response following $24 \mathrm{~h}$ exposure to PGN (Figure 1A). Taking $0.1 \mu \mathrm{g} / \mathrm{ml}$ as the lowest concentration to induce a response a real time PCR time course showed that IL-6 mRNA expression was induced 6-12 h following challenge (Figure 1B) and a $6 \mathrm{~h}$ time-point was used in subsequent experiments to monitor IL-6 mRNA expression levels. Similar effects were seen for TNF $\alpha$ (data not shown).

\section{The impact of PGN on Cx expression and gap junction functionality:}

Reverse transcription PCR detected $\mathrm{Cx} 43$ and $\mathrm{Cx} 45$ transcripts, but not $\mathrm{Cx} 40$ or $\mathrm{Cx} 37$ in the b.End5 cells (Figure 2A). Following exposure of b.End5 cells to $0.1 \mu \mathrm{g} / \mathrm{ml}$ PGN, real time PCR analysis determined that PGN induced a transient increase in Cx43 mRNA expression, peaking at $6 \mathrm{~h}$ (Figure 2B). This increase in mRNA expression correlated with an increase in $\mathrm{Cx} 43$ protein expression and a change in phosphorylation levels following $6 \mathrm{~h}$ exposure to PGN as determined by western blot analysis (Figure 2C). Upon further exposure to PGN, Cx43 expression levels returned to basal levels. In subsequent experiments a $6 \mathrm{~h}$ time-point was used to monitor Cx43 mRNA expression levels. Gap junctional functionality was also transiently increased. Under control conditions the ability of cells to transfer Alexa 488 following microinjection of the dye was restricted to $3-4$ neighbouring cells, by contrast following challenge with PGN for $6 \mathrm{~h}$ a significant increase in the number of cells transferring the small fluorescent dye Alexa 488 was observed (Figure 2D). Following $24 \mathrm{~h}$ challenge with PGN dye transfer was still significantly higher than controls although lower than at the $6 \mathrm{~h}$ time point (Figure 2D). Trypan blue exclusion assays confirmed that cells were still viable.

\section{The effect of PGN on Hemichannel activity in b.End5 cells}

To determine if PGN impacted on hemichannel activity we performed a range of ATP and NAD release assays in the presence and absence of a variety of established hemichannel blockers. To validate that hemichannel activity could be readily assayed b.End5 cells were challenged for 15 min with the reducing agent DTT in the presence or absence of the generic Cx blocker 18 $\alpha-\mathrm{GA}$. Under control conditions a limited amount of ATP was detected in the media, however following exposure to $10 \mathrm{mM}$ DTT an increase (4-fold) in ATP was found, a stimulation that was reduced by cotreatment with $18 \alpha-\mathrm{GA}$ (Figure 3A), in agreement with similar studies by Retamal et al [23]. A time course of PGN exposure revealed a transient increase in ATP release (2-fold), peaking at $15 \mathrm{~min}$, with little significant differences to mock challenged cells at time points thereafter (up to $4 \mathrm{~h}$ ) (Figure 3B). In all subsequent hemichannel assays cells were challenged with PGN for $15 \mathrm{~min}$. To confirm that this acute release of ATP was associated with hemichannel opening cells were challenged with PGN following pre-exposure to the hemichannel blockers LN, CBX or the Cx mimetic peptide Gap26 for $1 \mathrm{~h}$. Under control conditions, i.e. in the absence of PGN, none of the blockers had any significant effect on the level of ATP in the media compared to mock challenged cells (Figure 3C). By contrast challenge with PGN resulted in at least a 2-fold increase in ATP levels that was significantly attenuated with each of the blockers (Figure 3C). Following PGN challenge an increase in NAD levels in cell supernatants was recorded that was attenuated by treatment with both Gap26 and CBX (Figure $3 \mathrm{D})$, agreeing with reports that hemichannel opening can also trigger release of NAD from cells [23]. Further, a dose response to CBX in b.End5 cells illustrated that concentrations lower than $50 \mu \mathrm{M}$ failed to significantly inhibit ATP release (Figure 
3E). LDH levels were maintained at basal levels under the different treatments thereby confirming cell viability (Figure 3F).

The acute hemichannel response was not associated with any rapid changes in $\mathrm{Cx} 43$ mRNA expression (Figure 2B).To investigate whether post-translational modification of Cx43 occurred we performed Western blots on b.End5 cells exposed to PGN for 15 min. This correlated with an acute increase in $\mathrm{Cx} 43$ expression and phosphorylation (Figure 4A). Interaction of PGN with TLR2 induces a range of downstream signalling events including activation of protein kinase $C[29,30]$. Treatment of the cells with Chelerythrine, a protein kinase $\mathrm{C}$ inhibitor, had little effect on the expression profile of $\mathrm{Cx} 43$ determined by an antibody recognising total $\mathrm{Cx} 43$ (Figure $4 \mathrm{~B}, \mathrm{r}-\mathrm{Cx} 43$ ). By contrast, phosphorylation of serine 368 on the carboxyl tail of $\mathrm{Cx} 43$, known to be phosphorylated by PKC was removed following treatment with Chelerythrine (Figure $4 \mathrm{C}$, ser368). However, PGN had little effect on the level of p368 phosphorylation (Figure 4C). Experiments were performed to determine the impact of PGN and Chelerythrine on ATP release. Cells were pretreated with Chelerthyrine for $15 \mathrm{~min}$ prior to PGN challenge. In the presence or absence of PGN, Chelerthyrine induced a small ATP response above non treated control samples. However, this was low in comparison to the signal elicited by PGN alone suggesting a role for PKC in PGN induced hemichannel activity (Figure 4D).

\section{The effect of PGN on Hemichannel activity in HeLa cells:}

To clarify a role for $\mathrm{Cx}$ signalling in these events we performed further experiments in $\mathrm{HeLa}$ OHIO cells (that do not express $\mathrm{Cx} 43$ and are GJ communication deficient) and in HeLa cells stably transfected to express Cx43 (HeLa43). Reverse transcription PCR analysis confirmed that the HeLa43 cells had the same Cx expression profile as the b.End5 cells, by contrast only Cx45 was detected in HeLa OHIO cells (Figure 2A). When HeLa 43 cells were challenged with PGN a 3-fold increase in levels of extracellular ATP was detected that was blocked with 50 $\mu \mathrm{M}$ CBX (Figure 5A). By contrast, challenge of the $\mathrm{Cx} 43$ deficient HeLa OHIO cells with PGN did not induce an ATP response (Figure 5A). Furthermore, transient transfection of HeLa OHIO cells with a plasmid expressing Cx43-GFP, hence overexpressing Cx43, induced a 6.5-fold increase in extracellular ATP levels that was blocked by $50 \mu \mathrm{M} \mathrm{CBX}$. By contrast cells transfected with pEGFP-N1 did not respond to PGN stimulation (Figure 5B). Transfection efficiencies for the two constructs were comparable, as determined by GFP fluorescence. Taken together these findings suggest that the observed ATP release caused by PGN is due to acute activation of $\mathrm{Cx} 43$ hemichannels.

\section{Attenuation of CX43 Hemichannel activity inhibits induction of IL-6 and TLR2 expression:}

Following challenge of the b.End5 cells with PGN for $6 \mathrm{~h}$ TLR 2 and IL-6 expression were both induced at the mRNA level (Figure 1B and Figure 6A respectively) with enhanced protein expression readily detected by ELISA (IL-6, measured at $24 \mathrm{~h}$ post challenge) (Figure 1A) and Western blot analysis (TLR2) where a band of $84 \mathrm{kDa}$ corresponding to TLR2 was detected following $12 \mathrm{~h}$ exposure to PGN (Figure 6B), however this antibody had to be used at low titres and no protein was detected at earlier time points. $\mathrm{Cx} 43 \mathrm{mRNA}$ and protein expression were also induced following $6 \mathrm{~h}$ exposure to PGN (Figure 2B). To determine if the acute hemichannel signalling observed following PGN challenge had any effect on the expression profile of these genes hemichannel activity was blocked by pre-exposure to CBX. The blocker was removed and cells challenged for 15 min with PGN prior to collection of media for 
ATP analysis or further exposure to PGN for $6 \mathrm{~h}$ before RNA was extracted. Exposure to PGN for $15 \mathrm{~min}$ induced an ATP response that was negated by pretreatment with $\mathrm{CBX}$, as seen in all other experiments (Figure 7A). Following preexposure to CBX i.e. absence of ATP release via Cx43 hemichannels, Cx43 mRNA expression was still induced following $6 \mathrm{~h}$ exposure to PGN (Figure 7B). By contrast, TLR2 and IL-6 expression were not induced when the initial hemichannel activity was blocked (Figure 7C and D). Addition of apyrase to the media, thereby degrading extracellular ATP levels, also attenuated the acute PGN induced ATP release (Figure 7E) and the later PGN induced expression of IL-6 and TLR2 but had no effect on Cx43 mRNA expression levels (Figure 7F -H). Similar effects to IL-6 were seen for TNF $\alpha$ expression (data not shown).

\section{Inhibition of TLR2 expression has no effect on PGN induced hemichannel activity}

Finally we sought to explore the role of TLR2 in the observed responses. Transfection of b.End5 cells with siRNA targeted to TLR2 efficiently reduced the induction of TLR2 expression by $6 \mathrm{~h}$ exposure to PGN (Figure 8A). The ability of $6 \mathrm{~h}$ exposure to PGN to induce Cx43 mRNA expression was also inhibited (Figure 8B). However, decreased TLR2 expression had no effect on the ability of PGN to induce hemichannel activity following $15 \mathrm{~min}$ of challenge (Figure 8C).

\section{Discussion}

The present work illustrates that challenge of endothelial cells with PGN isolated from S. epidermidis elicits an acute $\mathrm{Cx} 43$ hemichannel response that is required for the induction of TLR2 and IL-6 expression. This data adds to the range of bacterial cell wall components and pro-inflammatory agents that illicit $\mathrm{Cx}$ mediated signalling events and establishes a central role for acute hemichannel signalling in induction of the innate immune response in endothelial cells.

The impact of pro-inflammatory mediators including PGN and gram negative derived LPS on cellular events is often studied at 6-24 h time points following challenge (e.g. $[14,17]$. Using a mouse endothelial model cell line (b.End5) we determined that PGN induced IL- 6 and TLR2 mRNA expression within $6 \mathrm{~h}$ of exposure, demonstrating the potent pro-inflammatory effect of PGN that is observed in diverse cell types including microglia, astrocyctes and synovial fibroblasts where staphylococci are prevalent pathogens. The impact of such pro-inflammatory mediators on $\mathrm{Cx}$ expression and function has highly cell specific effects. In astrocytes PGN inhibits GJ communication and $\mathrm{Cx} 43$ expression following $6 \mathrm{~h}$ challenge, by contrast in microglial cells $S$. aureus derived PGN induced Cx43 expression and gap junction communication [13, 14]. In the present work we demonstrate that PGN, isolated from S. epidermidis, transiently enhanced Cx43 mRNA and protein expression, peaking at $6 \mathrm{~h}$, which was associated with increased GJIC in our endothelial cell model. Thus our results clearly show that PGN influences Cx43 expression and function in endothelial cells at $6 \mathrm{~h}$ time points. Increased Cx43 protein expression was associated with an increase in the overall phosphorylation of the protein. The phosphorylation status of the carboxyl tail of Cx43 is influenced by subtle localised cellular events and is under the influence of protein kinase C, c-src and MAP kinase signalling pathways [31]. Changes in the phosphorylation status of $\mathrm{Cx} 43$ has profound and cell type specific effects on both GJIC and hemichannel signalling events. For example rapid serine 368 phosphorylation of $\mathrm{Cx} 43$ during hypoxia is associated with inhibition of $\mathrm{Cx} 43$ 
hemichannel activity in endothelial cells [32]. The extracellularly located PGN initiates its pro-inflammatory response by interaction with TLR2 receptors on the cell surface that are located in caveolin-A associated lipid raft domains where $\mathrm{Cx} 43$ also resides [33, 34]. An early event in TLR2 signalling is activation of c-Src and protein kinase $C$ that could explain the rapid phosphorylation of Cx43 observed following 15 min PGN challenge and may influence Cx43 signalling within the localised vicinity. Our data indicate that this was not linked with changes in the level of serine 368 phosphorylation. However, other phosphorylation changes cannot be ruled out particularly as TLR2 activation has been closely linked with induction of Cx43 expression and phosphorylation in airway epithelial cells [35].

Under normal physiological extracellular calcium concentrations hemichannels are closed [6]. Increasing evidence suggests that pathophysiological conditions can alter hemichannel activity releasing ATP, NAD and other extracellular signalling molecules that will impact on purinergic and downstream signalling pathways. Following exposure to PGN for periods of $15 \mathrm{~min}$ we determined that b.End5 cells acutely released ATP and NAD into the media suggestive of hemichannel opening. ATP release via hemichannels is an area of increasing interest due to the downstream pathological events this can lead to. 'Leaky hemichannels' arising in $\mathrm{Cx} 26$ and $\mathrm{Cx} 30$ mutations are associated with profound skin disorders often leading to apoptosis [36-38]. Ischemia and hypoxic insult are reported to open $\mathrm{Cx} 43$ hemichannels in cardiacmyocytes [24] and microglial cells [39], while hypoxic insult inhibits hemichannel activity in endothelial cells [32]. LPS and pro-inflammatory cytokines have also recently been shown to elicit a hemichannel response in astrocytes [12].

Until recently Cxs were considered to be the only family of proteins involved in gap junction intercellular communication in vertebrates. However, a second protein family, the pannexins (Panx 1, Panx 2, and Panx 3) has recently been identified [40]. These glycosylated, mechanosensitive channels also result in the release of ATP with associated purinergic signalling events in diverse cell types and considerable controversy over the precise role of Cxs versus Panxs in hemichannel signalling has emerged [40-43]. The b.End5 cells expressed Panx1 mRNA and limited Panx1 protein was detected by Western blot with limited diffuse intracellular staining detected by immunoflourescence (data not shown). A range of highly selective inhibitors are now available to distinguish between these two channels [40, 44]. LDH assays determined that PGN challenge did not damage cellular integrity and the ATP and NAD release was attenuated by the Cx mimetic peptide Gap26. Gap26 has been widely used as a highly specific inhibitor of $\mathrm{Cx}$ function in mammalian cells both in vitro and in vivo [12, 45-48]. The trivalent cation $\mathrm{La}^{3+}$ also attenuated ATP release that has been robustly shown by others to attenuate $\mathrm{Cx}$ but not Panx hemichannels in a variety of cell types and assays (reviewed by [44]). Panx hemichannel activity is also more sensitive to the blocker carbonoxolone than $\mathrm{Cx}$ hemichannels [49]. At doses of $50 \mu \mathrm{M}, \mathrm{CBX}$ attenuated ATP release in b.End5 cells i.e. at levels reported to attenuate $\mathrm{Cx}$ and Panx channels. However, doses below $25 \mu \mathrm{M}$ CBX had no effect on ATP release further confirming the $\mathrm{Cx}$ mediated response PGN was delivering. We also performed experiments Cx43 deficient HeLa OHIO cells [19, 20] where limited endogenous Panx protein expression has previously been reported [50]. PGN challenge elicited an ATP response in HeLa cells stably expressing Cx43 but not in non-transfected HeLa OHIO cells. In HeLa OHIO cells transiently transfected to over-express Cx43-GFP, a large ATP response was induced all of which were attenuated by $50 \mu \mathrm{M} C B X$. The fact that in vertebrates Cxs 
and Panxs are co-expressed in many cell types and are evolutionarily distinct implies that both protein families have their own specific function. Our data point towards $\mathrm{Cx}$ hemichannel activity being the initial trigger following challenge of endothelial and HeLa cells with PGN.

Extracellular ATP can initiate downstream purinergic signalling responses leading to pro-inflammatory cytokine release. Recent evidence indicates that ATP released from LPS-activated microglia signals through P2X receptors thereby augmenting pro-inflammatory cytokine production [51]. A further study suggested that Shigella infection of epithelial cells triggers ATP release through Cx26 hemichannels, resulting in the activation of purinergic receptors on neighbouring cells and bacterial dissemination [52]. Thus we hypothesised that the acute PGN induced ATP release would trigger purinergic signalling events ultimately leading to the enhanced gene expression observed. Blockage of the acute ATP release by pretreating the endothelial cells with CBX or removing extracellular ATP by apyrase, followed by continued exposure to PGN for $6 \mathrm{~h}$, prevented the PGN induced TRL2 and IL-6 expression. However, inhibition of hemichannel activity had no impact on the PGN induced expression of $\mathrm{Cx} 43$ mRNA. These results suggest that localised membrane responses to PGN, acutely activate $\mathrm{Cx} 43$ hemichannels causing a transient ATP release that alerts cells of bacterial challenge thus providing a local way of priming cells of infection, possibly via purinergic signalling events. Inhibition of protein kinase $\mathrm{C}$ with Chelerythrine caused a significant reduction in PGN induced ATP release suggesting that protein kinase $C$ pathways play a role in triggering the response, although as discussed this was not due to ser368 phosphorylation. PGN interacts directly with TLR2 leading to a sequence of events that ultimately activates signal transduction pathways, including those involved in nuclear factor- $\kappa \mathrm{B}(\mathrm{NF}-\kappa \mathrm{B})$ and mitogen-activated protein kinase (MAPK) [53]. This in turn would induce changes in $\mathrm{Cx}$ expression and gap junction coupling. TLR2 regulation of $\mathrm{Cx}$ expression and GJIC has recently been reported in airway epithelial cells [35] and in the intestinal epithelial barrier [54] supporting our observations. To clarify this link in our studies we transfected B.end5 cells with siRNA targeted to TLR2 and performed PGN challenges $24 \mathrm{~h}$ post transfection. This prevented PGN induced TLR2 and Cx43 mRNA expression re-enforcing a role for TLR2 signalling in the changes in Cx43 expression and gap junction function observed following $6 \mathrm{~h}$ exposure to PGN. However, following 15 min challenge with PGN, cells transfected with TLR2 siRNA still elicited an acute ATP response. This maybe due to residual endogenous TLR2 protein being present in the membrane and sufficient to trigger localised membrane responses resulting in hemichannel signalling.

In conclusion our data clearly illustrate for the first time that Gram positive bacterial cell wall components elicit an innate immune response that is associated with acute activation of $\mathrm{Cx} 43$ hemichannels. These events are likely driven by localised, early responses at the plasma membrane and occur prior to an increase in Cx43 expression and GJ coupling that are associated with TLR2 activity. The data further support the emerging concept that $\mathrm{Cx}$ hemichannel activity is intrically linked to infection and inflammatory conditions in diverse tissues including the endothelium (this work), lung epithelia [47] and the gut [52, 55]. As Cxs emerge as proteins amenable to direct therapeutic targeting by siRNA strategies [56] and highly specific peptides that can inhibit $[47,48,55]$; or enhance coupling [26] further work defining the signalling cascades involved is an area of important future research. 


\section{Acknowledgements:}

We would like to thank Dr. Edgar Rivedal for supply of the Cx43 antibody, Zealand Pharma for the supply of Gap26. We are indebted to Prof Malcolm Hodgins for proof reading the manuscript and continued support. JR was supported by a GCU studentship.

\section{References}

1 Castellheim, A., Brekke, O. L., Espevik, T., Harboe, M. and Mollnes, T. E. (2009) Innate immune responses to danger signals in systemic inflammatory response syndrome and sepsis. Scand. J. Immunol. 69, 479-491

2 Hickey, M. J. and Kubes, P. (2009) Intravascular immunity: the host-pathogen encounter in blood vessels. Nat. Rev. Immunol. 9, 364-375

3 Chaytor, A. T., Evans, W. H. and Griffith, T. M. (1998) Central role of heterocellular gap junctional communication in endothelium-dependent relaxations of rabbit arteries. J. Physiol. 508, 561-573

4 Oviedo-Orta, E. and Howard Evans, W. (2004) Gap junctions and connexin-mediated communication in the immune system. Biochim. Biophys. Acta. 1662, 102-112

5 Johnstone, S., Isakson, B. and Locke, D. (2009) Biological and biophysical properties of vascular connexin channels. Int. Rev. Cell Mol. Biol. 278, 69-118

6 Evans, W. H., De Vuyst, E. and Leybaert, L. (2006) The gap junction cellular internet: connexin hemichannels enter the signalling limelight. Biochem. J. 397, 1-14

7 Burnstock, G. (2002) Purinergic signaling and vascular cell proliferation and death. Arterioscler. Thromb. Vasc. Biol. 22, 364-373

8 Seiffert, K., Ding, W., Wagner, J. A. and Granstein, R. D. (2006) ATPgammaS enhances the production of inflammatory mediators by a human dermal endothelial cell line via purinergic receptor signaling. J. Invest. Dermatol. 126, 1017-1027

9 Bolon, M. L., Peng, T., Kidder, G. M. and Tyml, K. (2008) Lipopolysaccharide plus hypoxia and reoxygenation synergistically reduce electrical coupling between microvascular endothelial cells by dephosphorylating connexin40. J. Cell Physiol. 217, 350-359

10 Simon, A. M., McWhorter, A. R., Chen, H., Jackson, C. L. and Ouellette, Y. (2004) Decreased intercellular communication and connexin expression in mouse aortic endothelium during lipopolysaccharide-induced inflammation. J. Vasc. Res. 41, 323333

11 Eugenin, E. A., Eckardt, D., Theis, M., Willecke, K., Bennett, M. V. and Saez, J. C. (2001) Microglia at brain stab wounds express connexin 43 and in vitro form functional gap junctions after treatment with interferon-gamma and tumor necrosis factor-alpha. Proc. Nat1. Acad. Sci. U S A. 98, 4190-4195

12 De Vuyst, E., Decrock, E., De Bock, M., Yamasaki, H., Naus, C. C., Evans, W. H. and Leybaert, L. (2007) Connexin hemichannels and gap junction channels are differentially influenced by lipopolysaccharide and basic fibroblast growth factor. Mol. Biol. Cell. 18, 34-46

13 Esen, N., Shuffield, D., Syed, M. M. and Kielian, T. (2007) Modulation of connexin expression and gap junction communication in astrocytes by the gram-positive bacterium S. aureus. Glia. 55, 104-117

14 Garg, S., Md Syed, M. and Kielian, T. (2005) Staphylococcus aureus-derived peptidoglycan induces $\mathrm{Cx} 43$ expression and functional gap junction intercellular communication in microglia. J. Neurochem. 95, 475-483

15 Mattsson, E., Heying, R., van de Gevel, J. S., Hartung, T. and Beekhuizen, H. (2008) Staphylococcal peptidoglycan initiates an inflammatory response and procoagulant activity in human vascular endothelial cells: a comparison with highly purified lipoteichoic acid and TSST-1. FEMS Immunol. Med. Microbiol. 52, 110-117 
Smith, K., Perez, A., Ramage, G., Gemmell, C. G. and Lang, S. (2009) Comparison of biofilm-associated cell survival following in vitro exposure of meticillin-resistant Staphylococcus aureus biofilms to the antibiotics clindamycin, daptomycin, linezolid, tigecycline and vancomycin. Int. J. Antimicrob. Agents. 33, 374-378

17 Jones, K. J., Perris, A. D., Vernallis, A. B., Worthington, T., Lambert, P. A. and Elliott, T. S. (2005) Induction of inflammatory cytokines and nitric oxide in J774.2 cells and murine macrophages by lipoteichoic acid and related cell wall antigens from Staphylococcus epidermidis. J. Med. Microbiol. 54, 315-321

18 Wagner, E. F. and Risau, W. (1994) Oncogenes in the study of endothelial cell growth and differentiation. Semin. Cancer Biol. 5, 137-145

19 Elfgang, C., Eckert, R., Lichtenberg-Frate, H., Butterweck, A., Traub, O., Klein, R. A., Hulser, D. F. and Willecke, K. (1995) Specific permeability and selective formation of gap junction channels in connexin-transfected HeLa cells. J. Cell Biol. 129, 805-817

20 Johnstone, S. R., Best, A. K., Wright, C. S., Isakson, B. E., Errington, R. J. and Martin, P. E. (2010) Enhanced connexin 43 expression delays intra-mitotic duration and cell cycle traverse independently of gap junction channel function. J. Cell Biochem. 110, 772-782

Paemeleire, K., Martin, P. E., Coleman, S. L., Fogarty, K. E., Carrington, W. A., Leybaert, L., Tuft, R. A., Evans, W. H. and Sanderson, M. J. (2000) Intercellular calcium waves in HeLa cells expressing GFP-labeled connexin 43, 32, or 26. Mol. Biol. Cell. 11, 1815-1827

22 Ohta, K., Komatsuzawa, H., Sugai, M. and Suginaka, H. (1998) Zymographic characterization of Staphylococcus aureus cell wall. Microbiol Immunol. 42, 231-235

23 Retamal, M. A., Schalper, K. A., Shoji, K. F., Bennett, M. V. and Saez, J. C. (2007) Opening of connexin 43 hemichannels is increased by lowering intracellular redox potential. Proc. Natl. Acad. Sci. U S A. 104, 8322-8327

24 Clarke, T. C., Williams, O. J., Martin, P. E. and Evans, W. H. (2009) ATP release by cardiac myocytes in a simulated ischaemia model: inhibition by a connexin mimetic and enhancement by an antiarrhythmic peptide. Eur. J. Pharmacol. 605, 9-14

25 Leybaert, L., Braet, K., Vandamme, W., Cabooter, L., Martin, P. E. and Evans, W. H. (2003) Connexin channels, connexin mimetic peptides and ATP release. Cell Commun. Adhes. 10, 251-257

26 Easton, J. A., Petersen, J. S. and Martin, P. E. (2009) The anti-arrhythmic peptide AAP10 remodels Cx43 and Cx40 expression and function. Naunyn Schmiedebergs Arch. Pharmacol. 380, 11-24

27 Rivedal, E. and Leithe, E. (2005) Connexin43 synthesis, phosphorylation, and degradation in regulation of transient inhibition of gap junction intercellular communication by the phorbol ester TPA in rat liver epithelial cells. Exp. Cell Res. 302, 143-152

28 Coley, J., Duckworth, M., Baddiley, J. (1975) Extraction and purification of lipoteichoic acids from Gram-positive bacteria. Carbohydr. Res. 40, 41-52

29 Faisal, A., Saurin, A., Gregory, B., Foxwell, B. and Parker, P. J. (2008) The scaffold MyD88 acts to couple protein kinase Cepsilon to Toll-like receptors. J. Biol. Chem. 283, 18591-18600

30 Kumar, H., Kawai, T. and Akira, S. (2009) Pathogen recognition in the innate immune response. Biochem. J. 420, 1-16

31 Solan, J. L. and Lampe, P. D. (2009) Connexin43 phosphorylation: structural changes and biological effects. Biochem. J. 419, 261-272

32 Faigle, M., Seessle, J., Zug, S., El Kasmi, K. C. and Eltzschig, H. K. (2008) ATP release from vascular endothelia occurs across $\mathrm{Cx} 43$ hemichannels and is attenuated during hypoxia. PLoS One. 3, e2801

33 Soong, G., Reddy, B., Sokol, S., Adamo, R., Prince, A. (2004) TLR2 is mobilized into an apical lipid raft receptor complex to signal infection in airway epithelial cells.

J. Clin. Invest. 113, 1482-1489 
34 Langlois, S., Cowan, K.N., Shao, Q., Cowan, B.J., Laird, D.W. (2008) Caveolin-1 and -2 interact with connexin43 and regulate gap junctional intercellular communication in keratinocytes. Mol. Biol. Cell. 3, 912-928

35 Martin, F. J., Prince, A.S. (2008) TLR2 regulates gap junction intercellular communication in airway cells. J. Immunol. 180, 4986-4993

36 Sanchez, H. A., Mese, G., Srinivas, M., White, T. W. and Verselis, V. K. (2010) Differentially altered $\mathrm{Ca}^{2+}$ regulation and $\mathrm{Ca}^{2+}$ permeability in $\mathrm{Cx} 26$ hemichannels formed by the A40V and G45E mutations that cause keratitis ichthyosis deafness syndrome. J. Gen. Physiol. 136, 47-62

37 Tattersall, D., Scott, C. A., Gray, C., Zicha, D. and Kelsell, D. P. (2009) EKV mutant connexin 31 associated cell death is mediated by ER stress. Hum. Mol. Genet. 18, 4734-4745

38 Lee, J. R., Derosa, A. M. and White, T. W. (2009) Connexin mutations causing skin disease and deafness increase hemichannel activity and cell death when expressed in Xenopus oocytes. J. Invest. Dermatol. 129, 870-878

39 Orellana, J. A., Hernandez, D. E., Ezan, P., Velarde, V., Bennett, M. V., Giaume, C. and Saez, J. C. Hypoxia in high glucose followed by reoxygenation in normal glucose reduces the viability of cortical astrocytes through increased permeability of connexin 43 hemichannels. Glia. 58, 329-343

40 Dahl, G. and Locovei, S. (2006) Pannexin: to gap or not to gap, is that a question? IUBMB Life. 58, 409-419

41 Penuela, S., Bhalla, R., Gong, X. Q., Cowan, K. N., Celetti, S. J., Cowan, B. J., Bai, D., Shao, Q. and Laird, D. W. (2007) Pannexin 1 and pannexin 3 are glycoproteins that exhibit many distinct characteristics from the connexin family of gap junction proteins. J. Cell Sci. 120, 3772-3783

42 Ransford, G. A., Fregien, N., Qiu, F., Dahl, G., Conner, G. E. and Salathe, M. (2009) Pannexin 1 contributes to ATP release in airway epithelia. Am. J. Respir. Cell Mol. Biol. 41, 525-534

43 Kanneganti, T. D., Lamkanfi, M., Kim, Y. G., Chen, G., Park, J. H., Franchi, L., Vandenabeele, P. and Nunez, G. (2007) Pannexin-1-mediated recognition of bacterial molecules activates the cryopyrin inflammasome independent of Toll-like receptor signaling. Immunity. 26, 433-443

44 D'Hondt, C., Ponsaerts, R., De Smedt, H., Bultynck, G. and Himpens, B. (2009) Pannexins, distant relatives of the connexin family with specific cellular functions? Bioessays. 31, 953-974

45 De Vuyst, E., Wang, N., Decrock, E., De Bock, M., Vinken, M., Van Moorhem, M., Lai, C., Culot, M., Rogiers, V., Cecchelli, R., Naus, C.C., Evans, W.H., Leybaert, L. (2009) $\mathrm{Ca}^{2+}$ regulation of connexin 43 hemichannels in $\mathrm{C} 6$ glioma and glial cells. Cell Calcium 46, 176-187

46 Gomes, P., Srinivas, S. P., Van Driessche, W., Vereecke, J. and Himpens, B. (2005) ATP release through connexin hemichannels in corneal endothelial cells. Invest. Ophthalmol. Vis. Sci. 46, 1208-1218

47 Sarieddine MZ, S. K., Foglia B, Maass K, Garcia I, Kwak BR, Chanson M. (2009) Connexin43 modulates neutrophil recruitment to the lung. J. Cell Mol. Med. 13, 4560-4570

48 Pollok, S., Pfeiffer, A. C., Lobmann, R., Wright, C. S., Moll, I., Martin, P. E. and Brandner, J. M. (2010) Connexin 43 mimetic peptide Gap27 reveals potential differences in the role of $\mathrm{Cx} 43$ in wound repair between diabetic and non-diabetic cells. J. Cell Mol. Med. 2010 Mar 19. [Epub ahead of print]

49 Bruzzone, R., Barbe, M.T., Jakob, N.J., Monyer, H. (2005) Pharmacological properties of homomeric and heteromeric pannexin hemichannels expressed in Xenopus oocytes. J Neurochem. 92, 1033-1043.

50 Penuela, S., Celetti, S. J., Bhalla, R., Shao, Q. and Laird, D. W. (2008) Diverse subcellular distribution profiles of pannexin 1 and pannexin 3. Cell Commun. Adhes. 15, 133-142 
51 Boucsein, C., Zacharias, R., Farber, K., Pavlovic, S., Hanisch, U. K. and Kettenmann, H. (2003) Purinergic receptors on microglial cells: functional expression in acute brain slices and modulation of microglial activation in vitro. Eur. J. Neurosci. 17, 2267-2276

52 Tran Van Nhieu, G., Clair, C., Bruzzone, R., Mesnil, M., Sansonetti, P. and Combettes, L. (2003) Connexin-dependent inter-cellular communication increases invasion and dissemination of Shigella in epithelial cells. Nat. Cell Biol. 5, 720-726

53 Uematsu, S. and Akira, S. (2006) Toll-like receptors and innate immunity. J. Mol. Med. 84, 712-725

54 Ey, B., Eyking, A., Gerken, G., Podolsky, D. K. and Cario, E. (2009) TLR2 mediates gap junctional intercellular communication through connexin-43 in intestinal epithelial barrier injury. J. Biol. Chem. 284, 22332-22343

55 Guttman, J. A., Lin, A.E., Li, Y., Bechberger, J., Naus, C.C., Vogl, A.W,, Finlay, B.B. (2009) Gap junction hemichannels contribute to the generation of diarrhea during infectious enteric disease. Gut. 59, 218-226

56 Nakano, Y., Oyamada, M., Dai, P., Nakagami, T., Kinoshita, S. and Takamatsu, T. (2008) Connexin43 knockdown accelerates wound healing but inhibits mesenchymal transition after corneal endothelial injury in vivo. Invest. Ophthalmol. Vis Sci. 49, 93104 


\begin{tabular}{|c|c|c|c|c|}
\hline Gene & $\begin{array}{l}\text { Sense/ } \\
\text { Antisense }\end{array}$ & Forward 5'-3' /Reverse 5'-3' & $\begin{array}{l}\mathbf{T}_{\mathrm{a}} \\
\left({ }^{\circ} \mathbf{C}\right)\end{array}$ & $\begin{array}{l}\text { Band } \\
\text { size (bp) }\end{array}$ \\
\hline \multirow[t]{2}{*}{ Cx37 } & Sense & GGCTGGACCATGGAGCCGT & \multirow[t]{2}{*}{56} & \multirow[t]{2}{*}{421} \\
\hline & Antisense & TTTCGGCCACCCTGGGGAGC & & \\
\hline \multirow[t]{2}{*}{$\mathrm{Cx} 40$} & Sense & TTTGGCAAGTCACGGCAGGG & \multirow[t]{2}{*}{56} & \multirow[t]{2}{*}{311} \\
\hline & Antisense & TTGTCACTATGGTAGCCCTGAGG & & \\
\hline \multirow[t]{2}{*}{$\mathrm{Cx} 43$} & Sense & TACCACGCCACCGGC & & \multirow{2}{*}{407} \\
\hline & Antisense & AATCTCCAGGTCATCAGG & & \\
\hline \multirow[t]{2}{*}{$\mathrm{Cx} 45$} & Sense & AAAGAGCAGAGCCAACCAAA & \multirow[t]{2}{*}{56} & \multirow[t]{2}{*}{313} \\
\hline & Antisense & GTCCCAAACCCTAAGTGAAGC & & \\
\hline \multirow[t]{2}{*}{ GAPDH } & Sense & TGTTCCTACCCCCAATGTGT & \multirow[t]{2}{*}{72} & \multirow[t]{2}{*}{350} \\
\hline & Antisense & TGTGAGGGAGATGCTCAGTG & & \\
\hline \multicolumn{5}{|c|}{ Real-time Primers } \\
\hline \multirow[t]{3}{*}{$\mathrm{Cx} 43$} & Sense & TCATCTTCATGCTGGTGGTGTCCT & \multirow[t]{3}{*}{60} & \multirow[t]{3}{*}{156} \\
\hline & Antisense & TGGTGAGGAGCAGCCATTGAAGTA & & \\
\hline & Probe & TCCAAGGGCGTTAAGGATCGCGTGAA & & \\
\hline \multirow[t]{3}{*}{ IL-6 } & Sense & TTCCATCCAGTTGCCTTCTTG & \multirow[t]{3}{*}{60} & \multirow[t]{3}{*}{129} \\
\hline & Antisense & GGGAGTGGTATCCTCTGTGAAGTC & & \\
\hline & Probe & TGCTGGTGACAACCACGGCCTTC & & \\
\hline \multirow[t]{3}{*}{ GAPDH } & Sense & CACATGGCCTCCAAGGAGTAA & \multirow[t]{3}{*}{60} & \multirow[t]{3}{*}{134} \\
\hline & Antisense & TGAGGGTCTCTCTCTTCCTCTTGT & & \\
\hline & Probe & CTGGACCACCAGCAGCCCCAGCAAG & & \\
\hline
\end{tabular}

Table 1. Showing primer and probe sequences and annealing temperatures of Cxs, IL-6 and GAPDH sequences. The real-time probes all had 5'FAM and 3'TAMRA ends. 


\section{Figure Legends}

Figure 1 (A) b.End5 cells were challenged with 0-10 $\mu \mathrm{g} / \mathrm{ml}$ PGN for $24 \mathrm{~h}$. Culture media was collected and analysed for IL-6 expression by ELISA ( $n=3$ ). (B) mRNA was extracted $0,3,6,12$ and $24 \mathrm{~h}$ following treatment with $0.1 \mu \mathrm{g} / \mathrm{ml} \mathrm{PGN}$. Real-time PCR analysis determined that IL-6 mRNA expression was increased following 6 and $12 \mathrm{~h}$ exposure to PGN $(\mathrm{n}=4)\left({ }^{*} \mathrm{p}<0.05 ; * * \mathrm{p}<0.01 ; * * * \mathrm{p}<0.001\right)$.

Figure 2 (A) Cx mRNA expression profile in b.End5 (b), HeLa OHIO (O) and HeLa43 (43) cells. In each case mouse genomic DNA was used as a positive control. (B) Real time PCR analysis determined that $\mathrm{Cx} 43 \mathrm{mRNA}$ expression was induced following $6 \mathrm{~h}$ exposure to PGN $(\mathrm{n}=4)$. (C) An increase in the phosphorylation status of $\mathrm{Cx} 43$ occurred following $6 \mathrm{~h}$ challenge with PGN returning to control levels by 18 $\mathrm{h}(\mathrm{P}=\mathrm{PGN}, \mathrm{C}=\mathrm{Control}) . \beta$-tubulin was used as an internal control Representative blot $n=3$. (D). The effect of PGN on dye coupling in b.End5 cells. Monolayer's of cells were exposed to control conditions or PGN for 6 and $24 \mathrm{~h}$ after which individual cells were microinjected with the fluorescent tracer Alexa 488. Dye transfer was recorded following visualisation by fluorescence microscopy. Results expressed as average number of cells the dye transferred to. Data shown are the mean \pm SEM with statistical significance compared to corresponding controls $(n=3) . \quad\left({ }^{*} p<0.05\right.$; $* * \mathrm{p}<0.01 ; * * * \mathrm{p}<0.001)$.

Figure 3(A) b.End5 cells were exposed to DTT in the presence or absence of $18 \alpha$ GA for $1 \mathrm{~h}$ and extracellular ATP levels monitored $(\mathrm{n}=3)$. (B) b.End5 cells were exposed to PGN for up to $4 \mathrm{~h}$. Maximal ATP release occurred $15 \mathrm{~min}$ following challenge that was inhibited by the hemichannel blocker CBX $(n=3)$. This time point was used in all future ATP release assays. (C) A range of hemichannel blockers including Gap26, LN and CBX inhibited PGN induced ATP release in b.End5 cells $(n=3)$. (D) Challenge of b.End5 cells with PGN also induced NAD release that was attenuated by co-treatment with Gap26M and CBX (n=3). (E) Dose response of b.End5 cells to CBX, concentrations of CBX lower than $50 \mu \mathrm{M}$ failed to inhibit the PGN stimulated ATP release $(n=3)$. (F) LDH levels were unaltered in b.End5 cells following PGN challenge (not shown) $(n=3)$. $\left({ }^{*} p<0.05 ; * * p<0.01 ; * * *<0.001\right)$.

Figure 4 (A) b.End5 cells were treated with PGN for 15 min and total Cx43 protein expression determined by Western blot analysis. (B) Pretreatment of cells with Chelerythrine prior to PGN challenge for $15 \mathrm{~min}$ had no effect on total $\mathrm{Cx} 43$ protein expression (r-Cx43). Cx43 phosphorylation at position ser368 was not affected by PGN challenge and was efficiently removed following Chelerythrine treatment $(\mathrm{Cx} 43$-ser368). $\beta$-tubulin served as an internal loading control (representative blots $n=3$ ). (C) Exposure of $b$.End5 cells to Chelerythrine prior to PGN challenge reduced the level of ATP released $\left(* \mathrm{p}<0.05,{ }^{*} \mathrm{P}<0.01 ; \mathrm{n}=6\right)$.

Figure 5 (A) HeLa OHIO cells which do not express Cx43 and are communication incompetent showed no ATP release following exposure to PGN for $15 \mathrm{~min}$. In HeLa43 cells PGN induced a significant release of ATP compared to non treated cells that was attenuated with CBX $(n=3)$. (B) HeLa OHIO cells were transfected with Cx43-GFP or EGFP cDNA for $30 \mathrm{~h}$ prior to exposure to PGN $(n=6) . \quad\left({ }^{*} \mathrm{p}<0.05\right.$; $* * \mathrm{p}<0.01 ; * * * \mathrm{p}<0.001)$ 
Figure 6 (A) Real time PCR showed that TLR2 mRNA expression was induced following $6 \mathrm{~h}$ exposure to PGN $(\mathrm{n}=3)$. (C) Western blot analysis detected TLR2 protein expression $12 \mathrm{~h}$ following challenge with PGN. $\mathrm{P}=\mathrm{PGN}, \mathrm{C}=$ control. Representative blot $(\mathrm{n}=3) .(* * * \mathrm{p}<0.001)$.

Figure 7 (A) PGN induced ATP release after 15 min exposure in b.End5 cells which was inhibited by CBX $(n=3)$. (B) Pre-incubation of the cells with CBX prior to PGN challenge for $6 \mathrm{~h}$ had little effect on the induction of $\mathrm{Cx} 43 \mathrm{mRNA}$ expression by PGN $(\mathrm{n}=6)$. (C) Pre-incubation of the cells with CBX prior to PGN challenge for $6 \mathrm{~h}$ attenuated induction of IL-6 mRNA expression. (D) Pre-incubation of the cells with CBX prior to PGN challenge for $6 \mathrm{~h}$ attenuated induction of TLR2 $\mathrm{mRNA}$ expression $(\mathrm{n}=6)$. (E) PGN induced ATP release after 15 min exposure in b.End5 cells was inhibited by pre-exposure to apyrase $(n=3)$. (F) Pre-incubation of the cells with apyrase prior to PGN challenge for $6 \mathrm{~h}$ had little effect on the induction of $\mathrm{Cx} 43$ mRNA expression by PGN $(n=6)$. (G) Pre-incubation of the cells with apyrase prior to PGN challenge for $6 \mathrm{~h}$ attenuated induction of IL-6 mRNA expression. (H). Preincubation of the cells with apyrase prior to PGN challenge for $6 \mathrm{~h}$ attenuated induction of TLR2 mRNA expression $(\mathrm{n}=6) . \quad\left({ }^{*} \mathrm{p}<0.05 ; * * \mathrm{p}<0.01 ; * * * \mathrm{p}<0.001\right)$.

Figure 8 Transfection of b.End5 cells with siRNA targeted to TLR2 attenuated: (A) PGN induced TLR2 mRNA expression and (B) PGN induced Cx43 mRNA expression. (C) Transfection of b.EnD5 cells with siRNA targeted to TLR2 had no effect on PGN induced hemichannel activity $(n=3) . \quad\left({ }^{*} \mathrm{p}<0.05 ; \quad * * \mathrm{p}<0.01\right.$; $* * * \mathrm{p}<0.001)$. 
(A)

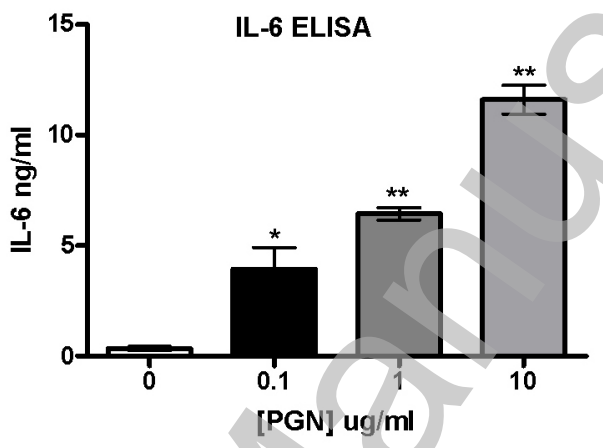

(B)
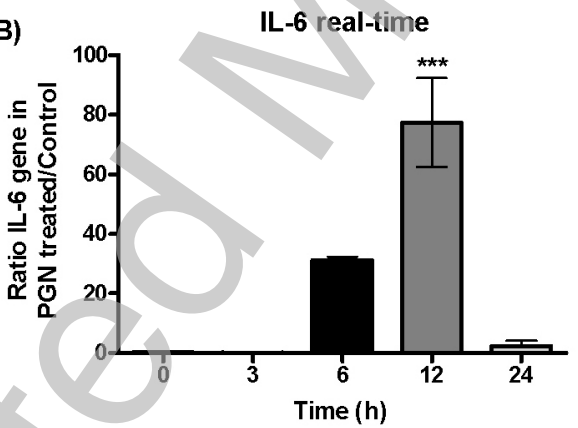

Figure 1 


\section{B Biochemical Journal Immediate Publication. Published on 03 Sep 2010 as manuscript BJ20091753}

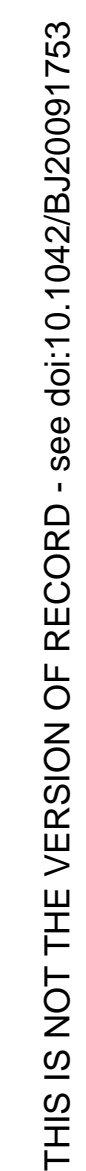

A)

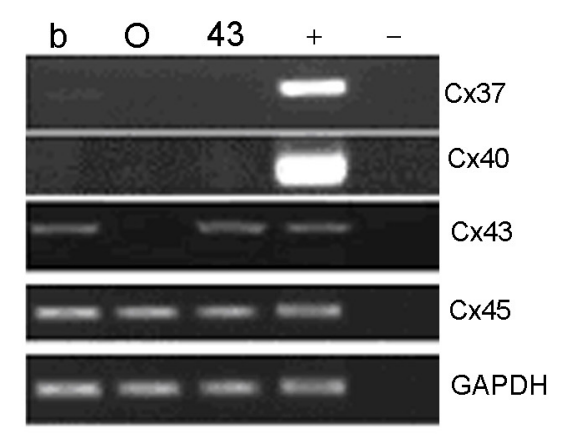

C)

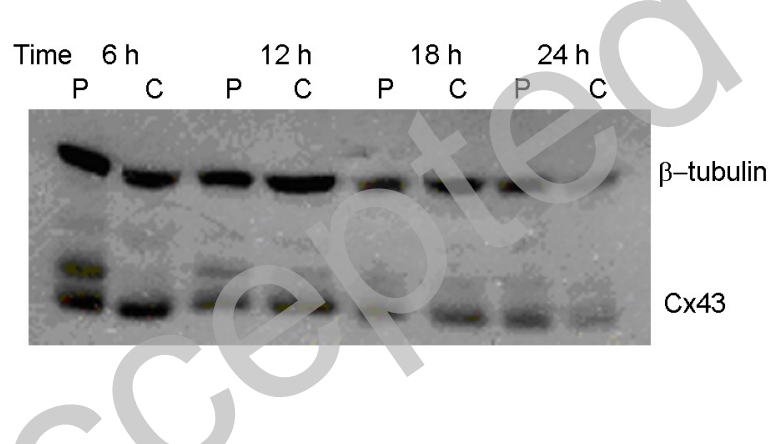

B)

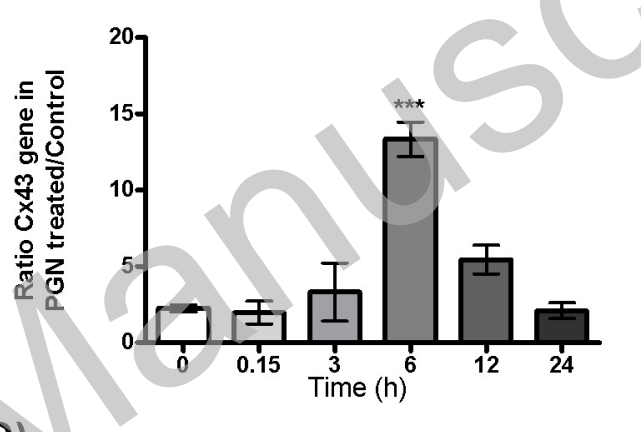

D)

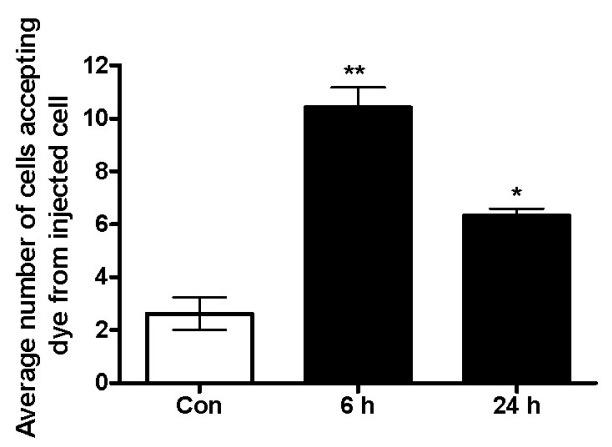

Figure 2 
Figure 3

(A)

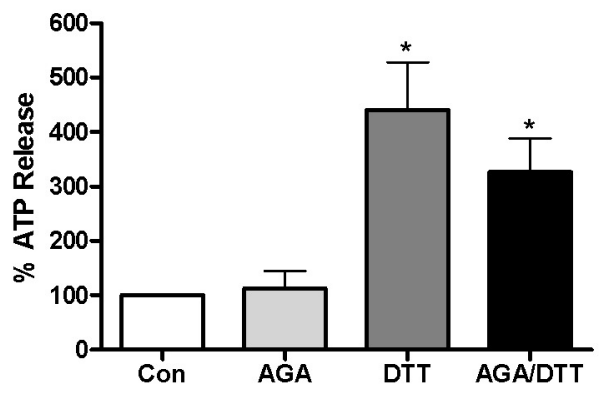

(C)

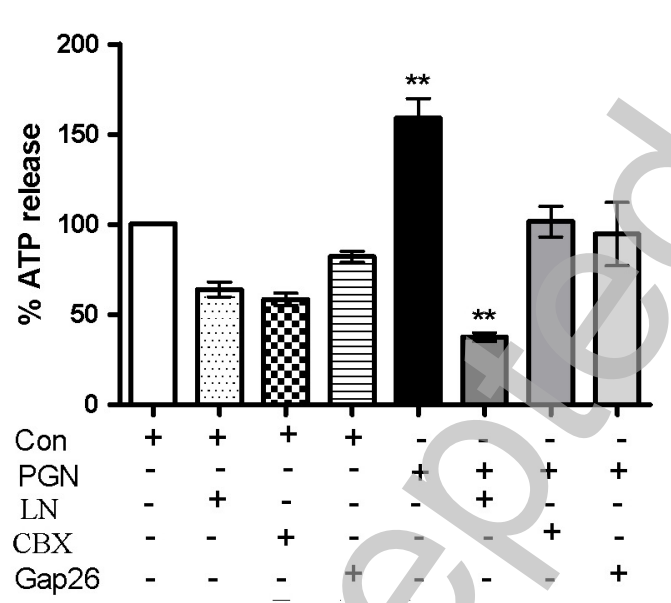

(E)

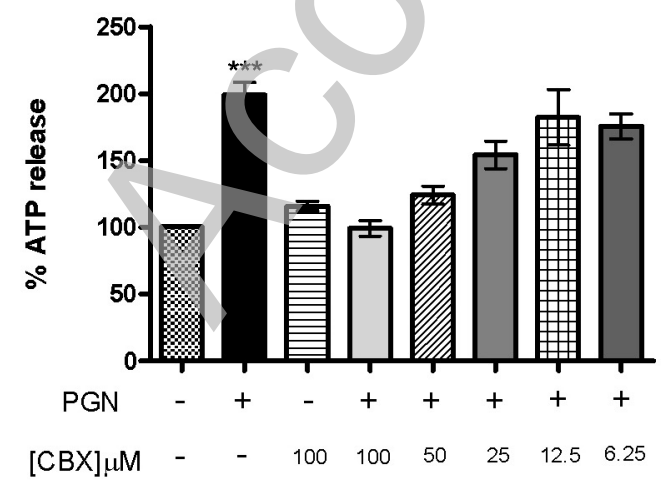

(B)

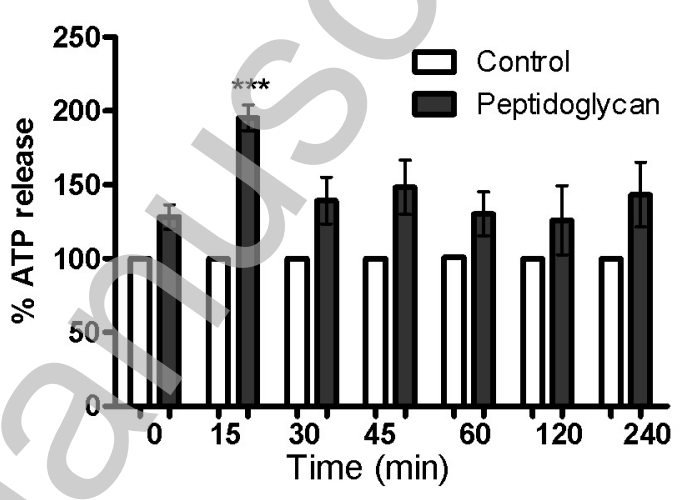

(D)

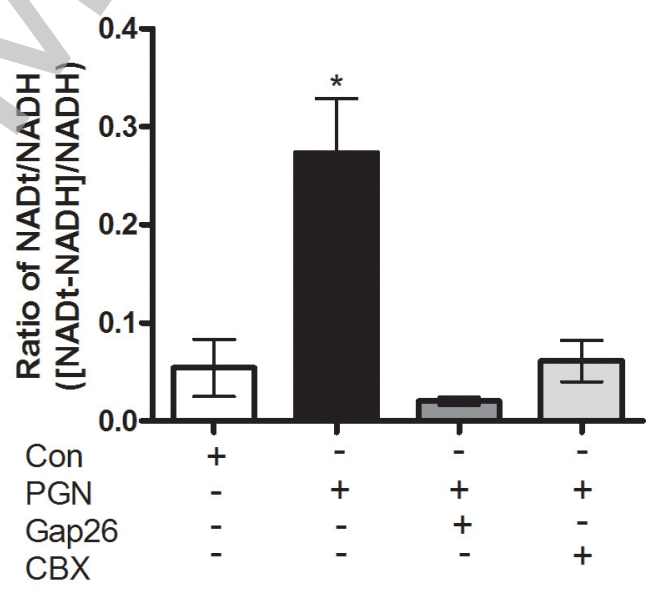

(F)

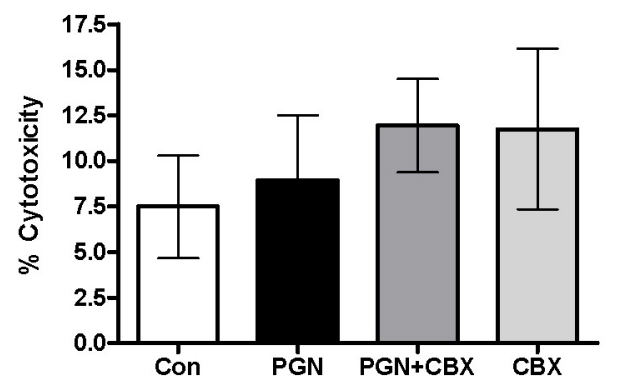


A)

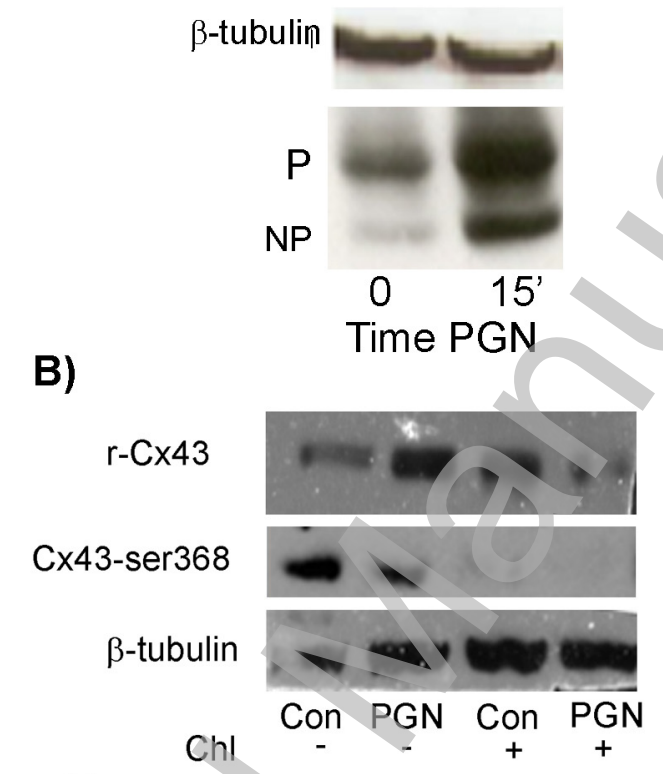

C)

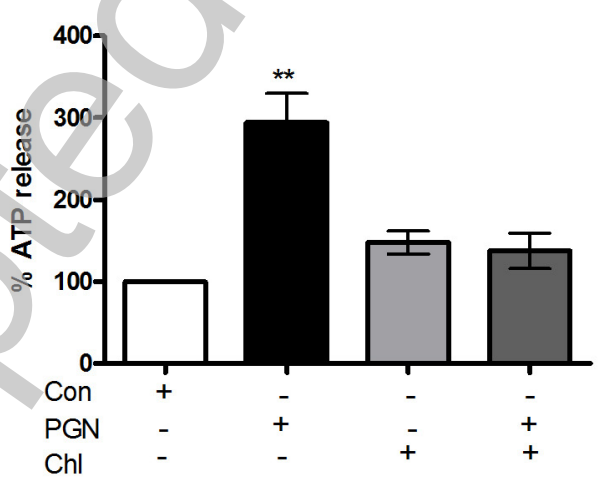

Figure 4 


\section{(A)}

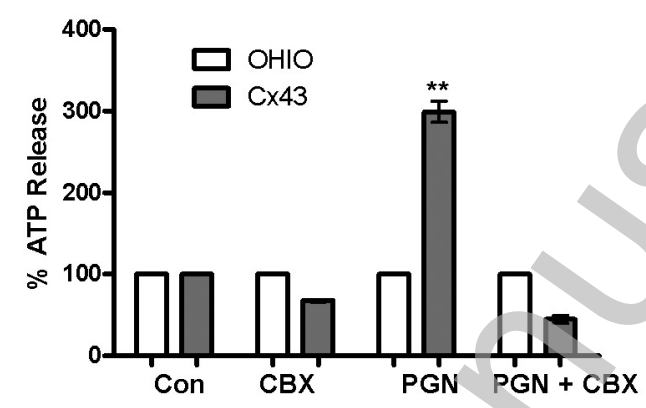

(B)

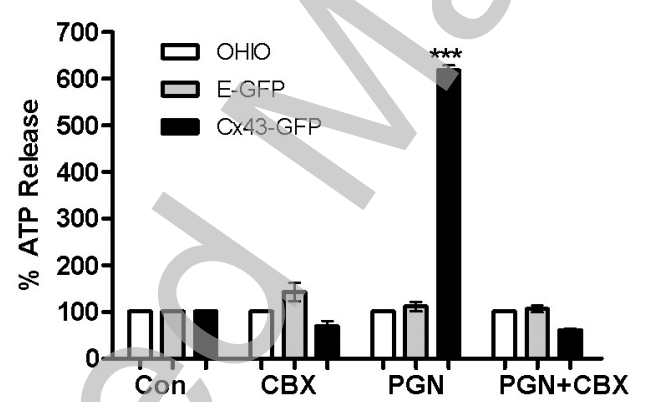

\section{Figure 5}


B Biochemical Journal Immediate Publication. Published on 03 Sep 2010 as manuscript BJ20091753

\section{A)}

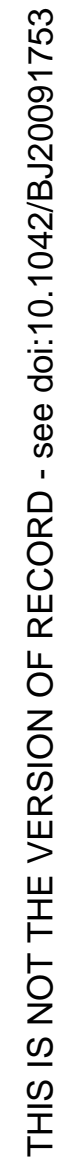

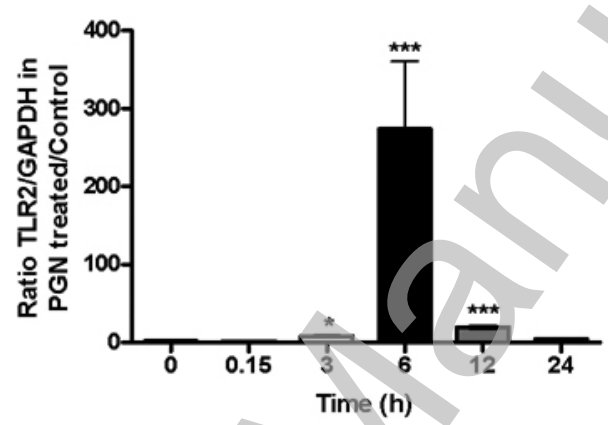

B)

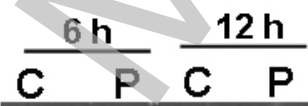

Figure 6

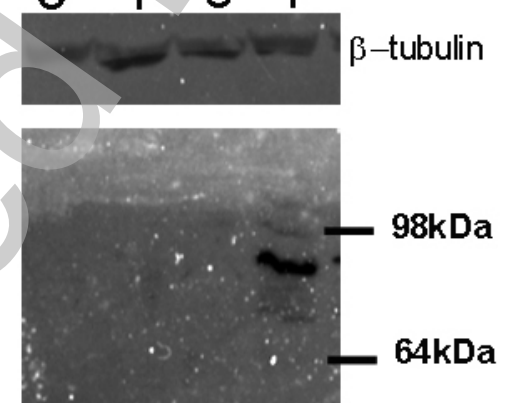




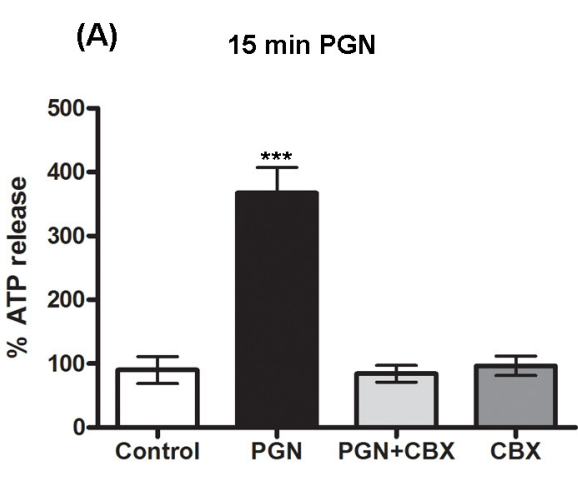

(E)

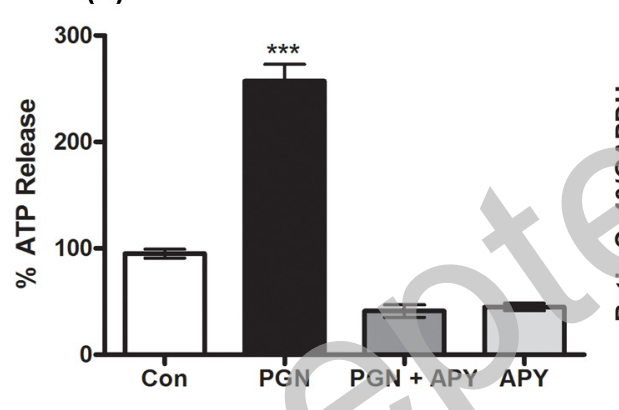

(F)
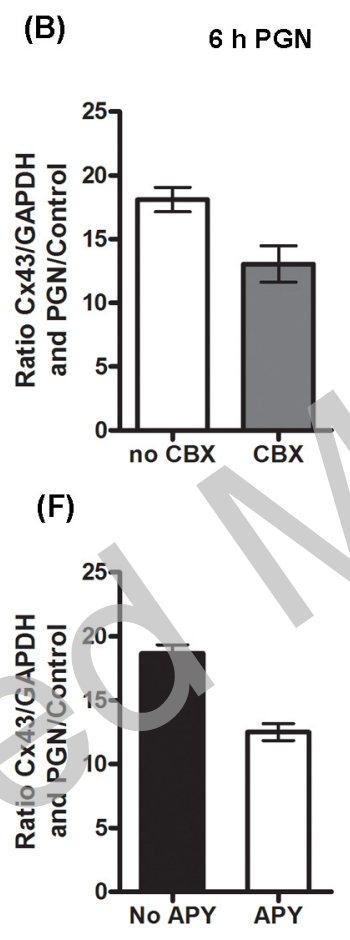

(C)

$6 \mathrm{~h} \mathrm{PGN}$

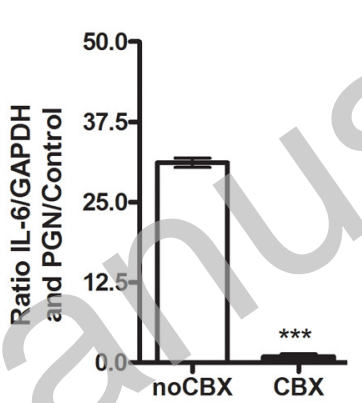

(G)

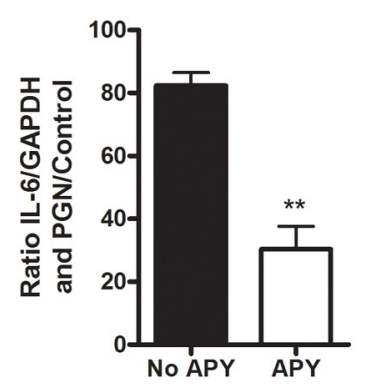

(D)

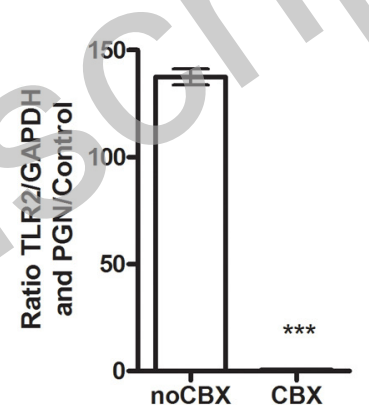

(H)

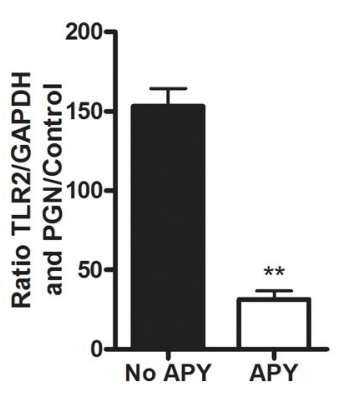

\section{Figure 7}




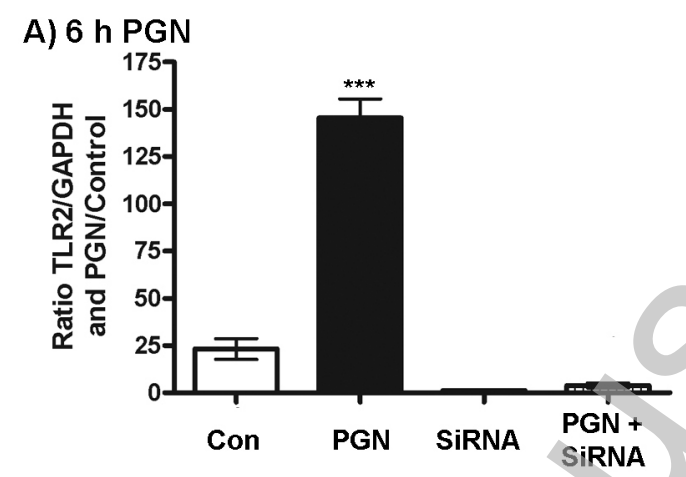

B) 6 h PGN

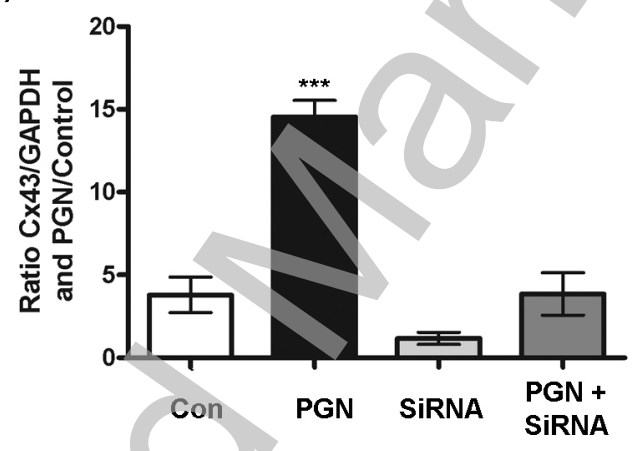

C) 15 min PGN

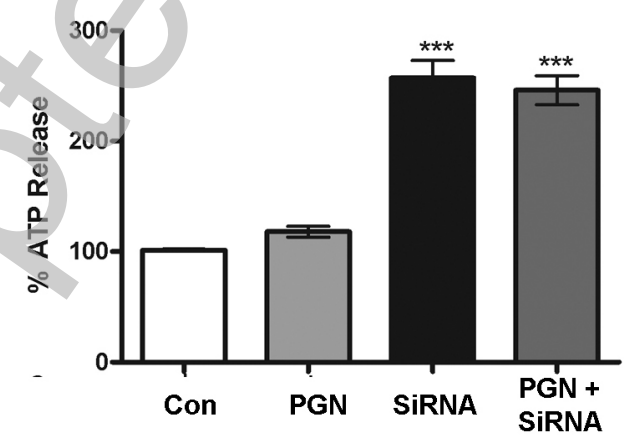

Figure 8 